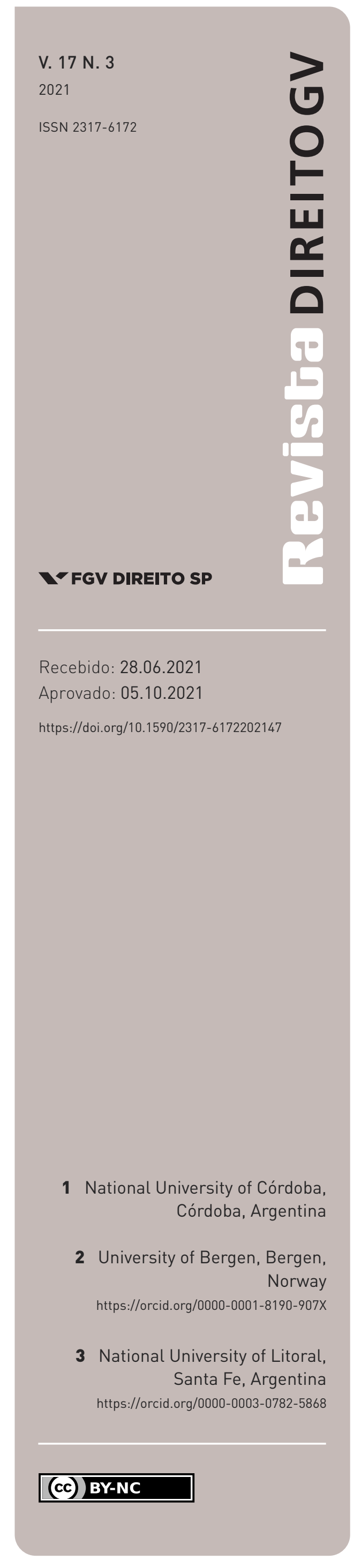

\section{Socio-Legal Strategies against a Total Abortion Ban in El Salvador: Alliances in Hostile Contexts}

\author{
ESTRATÉGIAS SOCIOJURÍDICAS CONTRA A PROIBIÇÃO TOTAL DO ABORTO EM EL SALVADOR: \\ ALIANCCAS EM CONTEXTOS HOSTIS
}

\author{
María Angélica Peñas Defago ${ }^{1,2}$ and Violeta Cánaves ${ }^{3}$
}

\begin{abstract}
The case of El Salvador provides unique evidence of how solidarity is possible among different social movements in struggles over abortion law reform and its impact, even in contexts of extreme criminalization. The paper depicts a concrete example of how networks centered on abortion struggles can go beyond feminist movements and national borders, and shows the domestic impact of broadening the scope of the audience, the actors involved, and the spheres where abortion law discussions take place. The article focuses on the evolution of socio-legal mobilization regarding abortion in El Salvador over the last two decades. This evolution is presented through three moments: the first centers on the legal actions that feminist movements orchestrated in the mid-2000's around the Beatriz case. The second moment focuses on the most outstanding features of the "Las 17" campaign - a collaborative and international experience that entailed the submission of seventeen pardon petitions on behalf of women who had been convicted of homicide after having miscarriages. Finally, a third moment entails the socio-legal strategies embraced by feminist movements since 2018 within the framework of the campaign named "Las 17+".
\end{abstract}

\section{Keywords}

Socio-legal mobilization; abortion; feminism; human rights; criminalization.

\section{Resumo}

O caso de El Salvador fornece uma evidência ímpar de como é possível a solidariedade entre diferentes movimentos sociais na luta pela reforma da legislação sobre aborto e seus impactos, mesmo em contextos de extrema criminalização. 0 artigo relata um exemplo concreto de como redes centradas nas lutas pelo aborto podem ultrapassar as fronteiras nacionais e dos movimentos feministas, e mostra o impacto nacional causado pela ampliação do debate público, dos atores envolvidos e das esferas de discussão que tratam do tema da legislação sobre aborto. É destacada a evolução da mobilização sociojurídica em relação ao aborto em El Salvador ao longo de duas décadas. Essa evolução é apresentada em três momentos: o primeiro é centrado nas ações jurídicas que os movimentos feministas orquestraram em meados dos anos 2000 sobre o caso Beatriz. 0 segundo momento analisa as características mais marcantes da campanha "Las 17", uma experiência internacional e colaborativa que envolveu a apresentação de dezessete petições de perdão judicial em nome de mulheres que foram condenadas por homicídio após terem sofrido abortos espontâneos. Por fim, o terceiro momento examina as estratégias sociojurídicas adotadas pelos movimentos de mulheres desde 2018 no âmbito da campanha "Las 17+".

\section{Palavras-chave}

Mobilização sociojurídica; aborto; feminismo; direitos humanos; criminalização. 


\section{INTRODUCTION ${ }^{1}$}

Social movements' use of legal tools can teach us strategies of resistance, resilience, and imagination, even in contexts that are extremely hostile to reproductive rights and where change might seem impossible. The case of El Salvador represents the most adverse and aggressive scenario for women's reproductive rights in Latin America and the Caribbean, for the country completely criminalizes abortion, even incarcerating women for more than thirty years for having spontaneous abortions.

The tensions around the recognition of sexual and reproductive rights in El Salvador have been a common feature in Latin America at the domestic and transnational level since the 1980s (HTUN, 2003; VAGGIONE, 2005; CORREA and PARKER, 2011; PECHENY and DE LA DEHESA, 2009). After the country's peace agreements of 1992 and during the process of democratic strengthening, conservative sectors designed an agenda regarding abortion that both defined and framed the fate of abortion politics in El Salvador for the years to come. Conservative legal reforms were achieved in the mid-1990s due mainly to a coalition among the Catholic Church hierarchy, the Catholic nongovernmental organization Sí a la Vida (meaning "yes to life"), ${ }^{2}$ and the right-wing political party Nationalist Republican Alliance, which held the presidency between 1992 and 2009 (FEUSIER, 2015; CENTER FOR REPRODUCTIVE LAW AND POLICY, 2001).

Before these reforms, the Criminal Code provided for some non-punishable abortions by creating exceptions for unintentional abortions, therapeutic abortions, abortions in cases of rape, and eugenic abortions (GOVERNMENT OF EL SALVADOR, 1973 and 1974). One of the consequences of these reforms, which established a total criminalization of abortion, was the severe persecution and criminal conviction of women who have had abortions or miscarriages. In El Salvador, one sees even the brutal persecution of women who have out-of-hospital deliveries due to obstetric emergencies.

In this context, a major focus of the feminist movements has been the use of legal (e.g., litigation and legal advocacy) and social strategies to shape the interpretations of judges and other public officials, as well as to change sociocultural perceptions of abortion and women's human rights in general.

1 This article was evaluated by Catarina Helena Cortada Barbieri, the editor-in-chief of Revista Direito GV, and by guest editors Camila Gianella and Marta Rodriguez de Assis Machado.

2 The NGO Sí a la Vida is the Salvadoran chapter of Vida Humana Internacional. Vida Humana Internacional was created in 1984 as a division of Human Life International. Under its leadership, various organizations in different countries in Latin America began to come together, including Ceprofarena in Peru (1981), the Movimiento Anónimo por la Vida in Chile (1985), and ProFamilia in Argentina (1983), all with the common agenda based on the defense of the sexual agenda promoted by the Vatican. 
Considering the Salvador case, the goal of this paper is to show one experience of legal mobilization led by feminist movements in a context of a total abortion ban. To this end, the paper focuses on the evolution of feminist socio-legal mobilization regarding abortion in El Salvador over the last two decades. This evolution is presented through three "moments". The first moment centers on the legal actions that feminist movements orchestrated in the mid2000s around the Beatriz case. This case is key to understand the abortion struggles in El Salvador, at both national and international levels. The second moment centers on the most outstanding features of the "Las 17" campaign, a collective and international experience that entailed the submission of seventeen pardon petitions on behalf of women who had been unjustly convicted of homicide after having miscarriages in advanced stages of pregnancy. Finally, the third moment entails the socio-legal strategies embraced by women's movements since 2018, within the framework of the campaign named "Las $17+{ }^{3}{ }^{3}$

Broadly, our analysis of abortion law reform in El Salvador centers on two key concepts: legal mobilization, from a human rights perspective, and transnational support networks.

The first of these, legal mobilization, entails civil society actors' adoption of national and international legal strategies, including litigation, to encourage political and legal reforms, as well as social change (MCCANN, 1994, 2006; VANHALA, 2018). In El Salvador, legal mobilization strategies have been intertwined with several regional experiences in which feminist movements, together with other movements and human rights organizations, seek legal reform through legal institutions (CABAL, ROA and SEPÚLVEDA, 2003; CABAL and TODD-GHER, 2009; JARAMILLO and SIERRA, 2018; RUIBAL, 2015). Furthermore, socio-legal mobilization in El Salvador has been framed in terms of the constitutionalization of abortion law, and in general in terms of women's autonomy, freedom, equality, and right to a life free from violence (SIEGEL, 2014; BERGALLO and RAMÓN MICHEL, 2018; BERGALLO, 2018; MACHADO and COOK, 2018).

On the other hand, the frame of human rights law has evolved into a founding platform in feminists' call for abortion law reform and also into one of the most frequently deployed discursive frameworks in legal briefs and extra-legal communication strategies (YAMIN, 2008; REBOUCHÉ, 2016; YAMIN and BERGALLO, 2017; BERER and HOGGART, 2019; STIFANI et al., 2018; RUIBAL and FERNANDEZ ANDERSON, 2020). This phenomenon

3 At the methodological level, a revision of different legal documents has been conducted: sentences, lawsuits, stenographic versions of legislative sessions of the penal and constitutional reforms related to the object of study, presentations to national and international human rights organisms, e-magazines on gender issues, relevant policy documents from various international non-governmental organizations, among others. In addition, the paper considers 13 interviews conducted in person by one of the researchers in El Salvador in 2014, 2015 and 2017 with key actors involved in the legal mobilization processes regarding abortion in this country. 
depicts the way in which international human rights law and human rights as a socio-political communication framework can function as a tool for cultural debates in a broad strategy beyond the judicial field.

The second key concept we will use to analyze the Salvadoran case refers to transnational support networks, or in the words of Margaret E. Keck and Kathryn Sikkink (1998) "transnational advocacy networks". These advocacy networks are established by women's coalitions of activists and defenders who share social values and whose actions go beyond legal and political reforms, trying to influence the terms of the debate itself. As expressed by Gillian Kane (2008), the creation of alliances and networks in Latin America, both local and transnational, has been a key component in advancing more permissive legislation on abortion. One of the features of these alliances is that they include not only feminist organizations but also other national and international human rights movements and organizations.

\section{I.The Beatriz CASE}

The democratic transition in El Salvador after the 1992 peace agreements created a context of tension between the government and women's movements, particularly after the election of Francisco Flores to the presidency (IRAHETA, 2009). At the same time, religious organizations successfully continued thwarting all attempts to advance sexual and reproductive rights (HERRERA ARGUETA and UGARTE, 2009).

Since the mid-2000s and after a series of articles about El Salvador published by the New York Times, the issue of abortion reemerged in the public arena. These articles described the serious consequences that the country's new regime of abortion criminalization were causing to the life of women (INTERVIEW WITH FEMINIST MOVEMENT LEADER, 2015). The reports inspired a gradual strengthening of feminist movements.

For example, following a New York Times article published in 2006 about Karina, a woman who was imprisoned after suffering a miscarriage (NEW YORK TIMES, 2006), several feminist activists from El Salvador joined forces with local private attorneys and international experts in medicine and criminology to promote the legal defense of Karina. One of the critical points of Karina's defense was the difficulty in obtaining access to scientific expertise: due to fear of legal and social retaliation, social organizations were unable to find a specialist from El Salvador willing to provide expert testimony. As a result, the organizations had to create alliances with international experts who officiated as external experts. ${ }^{4}$

4 Among those who supported this case as experts were María Castellano Arroyo, from the Department of Forensic Medicine, Toxicology and Psychiatry of the University of Granada, and Mariano Cantex, director of the Interdisciplinary Center for Forensic Research in Argentina. 
Thanks to the joint work of local feminists and their international allies, Karina was released from prison in 2009. This legal victory led to an important decision: to create Agrupación Ciudadana por la Despenalización del Aborto Terapéutico, Ético y Eugenésico (Citizens' Association for the Decriminalization of Therapeutic, Ethical, and Eugenic Abortion, hereinafter referred to as Agrupación Ciudadana). The creation of Agrupación Ciudadana is also connected with the experiences that were being carried out in other countries of the region that suffered legal reforms of total penalization, as is the case of Nicaragua in 2007:

Karina's result gave us a lot of hope, a lot of strength. That is the context in which we decided to create the Agrupación Ciudadana. In fact, at the beginning we also had some meetings with the Grupo Estratégico por la Despenalización del Aborto Terapéutico de Nicaragua GEDAT (Strategic Group for the Decriminalization of Therapeutic Abortion of Nicaragua). When we found out how they were working, a little inspired by that experience in Nicaragua, we created the Agrupación Ciudadana. (INTERVIEW WITH FEMINIST MOVEMENT LEADER, 2015)

In 2010, Agrupación Ciudadana brought a lawsuit to court claiming the unconstitutionality of the country's total criminalization of abortion. In 2011, the court rejected the claim and, reiterating a 2007 standard, ${ }^{5}$ ruled that when a maternal-fetal conflict of interests exists in cases of therapeutic and eugenic abortion, or in cases of rape, women can make use of the "necessity" defense outlined in article 27 of the Criminal Code in order to obtain a legal abortion (SALA CONSTITUCIONAL DE LA CORTE SUPREMA DE JUSTICIA, 2011).

Two years later, on April 11, 2013, Agrupación Ciudadana filed an amparo with the Supreme Court on behalf of Beatriz, a twenty-two-year-old woman who was seeking an abortion because she was seriously ill and pregnant with an anencephalic fetus. Both the country's health minister, María Isabel Rodríguez, and the board of directors from the hospital where Beatriz was hospitalized voiced their public support for Beatriz, positioning themselves in favor of the amparo (SALA CONSTITUCIONAL DE LA CORTE SUPREMA DE JUSTICIA, 2013).

5 In 1998, two law students brought an action of unconstitutionality to the Supreme Court of Justice against the 1998 Criminal Code, as part of their degree dissertation. They argued for the unconstitutionality on the grounds that the code did not include the traditional provisions for an abortion. In 2007, i.e. nine years after this process was started, the Supreme Court rejected the case, stating that the indications for abortion exceptions were still in force in the new regime, although tacitly. The Supreme Court ruled that these exceptions were included in the general causes for penalty exceptions which were part of Article 27 of the Salvadoran Penal Code. See Sentence 18, Constitutional Branch of the Supreme Court of Justice, 20 Nov. 2007. 
On April 18, 2013, and due to the lack of a timely response by the court, Agrupación Ciudadana and the Center for Justice and International Law presented a petition of precautionary measures $^{6}$ to the Inter-American Commission on Human Rights (hereinafter, IACHR) which were granted on April 29, 2013. On May 9, 2013, the IACHR reiterated to the State the precautionary measures granted in order to safeguard the life, personal integrity, and health of Beatriz (INTER-AMERICAN COURT OF HUMAN RIGHTS, 2013).

On May 20, the petitioners requested that the IACHR refer the case to the Inter-American Court of Human Rights for the adoption of precautionary measures.

Despite international mobilization, on May 28 the Supreme Court of El Salvador rejected the amparo, arguing that the Salvadoran Constitution protects life from the moment of conception (SALA CONSTITUCIONAL DE LA CORTE SUPREMA DE JUSTICIA, 2013). This decision reversed the standard used by the same Court in 2011, when it established that in cases of maternal-fetal conflict of interests, the "necessity" exception in the Criminal Code was applicable to access a legal abortion. The court denied Beatriz access to an abortion, in open contradiction with its 2011 decision.

The day after the Supreme Court's ruling, the Inter-American Court requested that the Salvadoran government make the necessary medical decisions to ensure the adequate protection of Beatriz's rights to life and to personal integrity (INTER-AMERICAN COURT OF HUMAN RIGHTS, 2013). Such measures amounted to a request for a therapeutic abortion, in line with the recommendations of Beatriz's doctors. These measures dictated by the InterAmerican Court became a transcendent precedent in the debates on abortion for the region in terms of the scope of the protection of the right to life, health, and sexual and reproductive rights in general (ARANGO OLAYA, 2014; FANNI, 2018). Regarding the protection of the right to life, the Inter-American Court ratifies its position in the Artavia Murillo case in relation to Article 4 of the Inter-American Convention by addressing the protection of the right to life of the unborn as incremental and gradual, and taking into consideration the other rights of women at stake. The Inter-American Court also referred to the need in Beatriz's case for comprehensive protection of her right to health and personal integrity, which includes her mental health (INTER-AMERICAN COURT OF HUMAN RIGHTS, 2012, par. 14).

6 According to the Inter-American Commission on Human Rights (2012) precautionary measures perform two functions related to protecting the fundamental rights enshrined in the rules of the inter-American system: they are "precautionary" in the sense of preserving a legal situation, or the subject of a petition, on which the Commission is to exercise its jurisdiction, and "protective" in the sense of preserving the exercise of human rights. The IACHR (2012) also points out that the "mechanism affords protection against irreparable harm to the beneficiary as a legal person under international human rights law. The irreparability requirement applies to circumstances in which the alleged victim cannot be compensated monetarily for his or her loss, or when it is impossible to restore the exercise of a violated right or indemnify the victims for the consequences of the violations that might be committed." 
Despite that, on June 3, when Beatriz was six months pregnant, she underwent a C-section in order to save the life of the fetus. About five hours after this medical intervention, the fetus, which had been born without a brain, died.

The massive media impact of the Beatriz case at the national and international levels not only created an intense debate on abortion in the Salvadoran public sphere but also helped strengthen the alliances that Agrupación Ciudadana had been constructing until that point. Among other factors, the extensive media coverage permitted Agrupación Ciudadana to strengthen its connections with other human rights organizations, at the local and international levels, in its struggle for the decriminalization of abortion in El Salvador.

In December 2013, the Colectiva Feminista para el Desarrollo Local de El Salvador (Feminist Collective for Local Development in El Salvador), Agrupación Ciudadana, IPAS Central America, and Center for Justice and International Law filed a petition before the IACHR against the Salvadoran State for the human rights violation suffered by Beatriz.

In their presentation, the petitioners argued the violations of the principle of legality and of the rights to life, to personal and family integrity suffered by Beatriz, in the following terms:

[T] he State failed to meet its obligation to respect the rights to life and personal integrity/human treatment of Beatriz and to fulfill its duty to prevent violations of those rights, a situation that, in addition, amounted to violence against women, due to the passive conduct of the health authorities who failed to proceed to interrupt the pregnancy, thereby allowing the pregnancy to continue past the 20th week and to require more extensive surgery, placing Beatriz's life at extreme risk and causing her and her family profound uncertainty and suffering. For that reason, the petitioners also allege violations of her family members' right to integrity. They further argue that these impairments to Beatriz's life, personal integrity and comprehensive health constituted cruel, inhuman, and degrading treatment and give rise to aggravated liability, due to noncompliance with the precautionary measures issued by the Commission. [...] the authorities violated Beatriz's right to privacy and personal integrity. Finally, they argue that the criminal laws in force on abortion violate the principle of legality given the situation of legal uncertainty generated for Beatriz, who was left not knowing whether she would in fact be prosecuted for consenting and proceeding with the interruption of the gestation of the anencephalic fetus, and that said legislation constitutes a regression vis-à-vis the State's international obligations to progressively achieve full materialization of the right to health. [...] the restrictive constitutional and criminal law that bans all forms of abortion in practice discriminates disproportionately against girls and women. (IACHR, 2017, par. 13)

In September 2017, the IACHR recognized that Beatriz's human rights had been violated and admitted the lawsuit against El Salvador. A month later and unaware of this news due 
to delays in the notification, Beatriz died due to a minor accident that had triggered a series of infections that her weakened body could not resist.

This was not the first accusation filed before an international human rights body against El Salvador as a consequence of the country's restrictive abortion law. In 2012, the Center for Reproductive Rights and Agrupación Ciudadana brought a case to the IACHR on behalf of Manuela, a thirty-three-year-old woman who died in 2010 due to an aggressive form of cancer that had been left untreated while she was in prison for having been convicted of homicide after suffering an obstetric emergency (INTER-AMERICAN COURT OF HUMAN RIGHTS, 2020). In July 2019, the IACHR filed an application to the Inter-American Court of Human Rights over case 13.069, Manuela and family vs. El Salvador.

After the Beatriz case, the Supreme Court ruled again on the country's abortion ban in a suit that did not directly involve feminist organizations. In 2014, one of the attorneys who had supported women's organizations in El Salvador, Víctor Hugo Mata Tobar, brought an unconstitutionality action once again, this time in his own name and not on behalf of feminist organizations (PEÑAS DEFAGO and CANAVES, 2018).

Despite the public impact that the Beatriz case had generated nine months before, the Supreme Court showed no change in its position and ruled just as it had done in 2007 and 2011. In other words, it ruled that the dispute between the rights of a fetus and those of a pregnant woman "may be perfectly settled by the duly reasoned recourse to some of the causes for penalty exception included in Article 27 of the Criminal Code" - exceptions that the same court did not take into consideration when ruling on Beatriz one year before (SALA CONSTITUCIONAL DE LA CORTE SUPREMA DE JUSTICIA, 2013).

After the Supreme Court's different rulings rejecting a broader interpretation of the country's abortion law, feminist organizations decided to follow a different path in their struggle for legal reform. However, they continued bringing cases to the courts on behalf of incarcerated women (INTERVIEW WITH FEMINIST MOVEMENT LEADERS, 2015, 2016). This is how the "Las 17 " campaign was born.

As we look at this first "moment" of feminist legal mobilization, we can see how, in each action that the movements prompted, there were considerations of the experiences in other countries, like the advantages and challenges that changes in the legal and political context could entail. One important example in this sense is the change in the political and social scene dating back to 2009. This year was not only the year of the creation of the Agrupación Ciudadana, but also the year when Mauricio Funes won the presidential election. This was the first time that the FMLN won an election since the peace accords. Despite Funes' resistance to opening the debate on abortion, certain issues pertaining to sexual and reproductive health advanced considerably during his term, ${ }^{7}$ which on

$\circ \cdot \bullet$

7 For example, in Funes' term, the reservations voiced by El Salvador at the Cairo Conference were removed, and a national policy on sexual and reproductive health was approved. 
different occasions made him come up against the pro-life movements and the catholic hierarchy (VITERNA, 2012).

This political change in the national administration was one of the key elements mentioned by feminist movements' analysis regarding opportunity settings before bringing the legal actions.

The Beatriz case was a turning point in legal mobilization around the legalization of abortion in El Salvador. The public exposure of the case's details helped unearth information about the different types of violence that a total ban on abortion could provoke. It also allowed feminist organizations to forge alliances with the health sector and the obstetrician-gynecologists' union, both of which had been reluctant to take a stand on abortion for years. Some of the resulting alliances collaborated in beginning a conversation between litigant organizations involved in the Beatriz case and the Ministry of Health. That dialogue led to the creation of a technical guide for health services, which helped health care providers obtain clarity about the law in cases of maternal-fetal conflicts of interests. After the Beatriz case, local women's organizations were able to begin working with the health sector and universities in a more coordinated manner and to provide health care providers with training sessions on how to adopt a gender perspective in their services. ${ }^{\mathbf{8}}$

\section{2. “LAS I7”: MAKING WOMEN AND THEIR STORIES Visible}

One of El Salvador's most complex problems is its brutal criminalization of women. The effects of the total abortion ban are twofold: (1) the persecution of women by the police and (2) the criminal conviction of women. Even women who have suffered miscarriages have been prosecuted and imprisoned. In many of these cases, the convictions do not even mention abortion and are categorized instead as aggravated homicide, in the midst of serious procedural deficiencies (VITERNA and GUARDADO, 2014). In this context, a conviction for abortion - which carries a maximum sentence of eight years in prison - may turn into fifty years in prison. Most of these criminal proceedings originate from police reports filed by public health care providers, the very individuals whom women turn to when seeking help (AGRUPACIÓN CIUDADANA, 2012).

After the failed cases brought to the Supreme Court, and as a consequence of strengthening experiences and alliances, in 2014 the Salvadoran feminist movement and its international allies submitted seventeen pardon petitions to the Legislative Assembly on behalf of women who had been unfairly convicted of homicide after suffering miscarriages. According to one

8 As examples we can mention the I Course on Human and Reproductive Rights, organized by the High Council of Public Health (Consejo Superior de Salud Pública,) the Feminist Collective Association for Local Development (Asociación Colectiva Feminista para el Desarrollo Local), Agrupación Ciudadana, and IPAS. 
of the movement's leaders, the strategy of "Las 17" was inspired by similar actions that the Mexican organization Las Libres had been conducting since $2010 .^{9}$ Also, the strategy of submitting pardon petitions had already been employed in El Salvador in 2007, by one of the lawyers who would later become a member of Agrupación Ciudadana (INTERVIEW WITH AGRUPACIÓN CIUDADANA'S ATTORNEY, 2017).

The central arguments of the pardon petitions filed by Agrupación Ciudadana - which were written by local attorneys in collaboration with specialists on human rights law and with international human rights organizations - emphasized the violation of the right to appeal (INTERVIEW WITH FEMINIST MOVEMENT LEADERS AND LAWYERS, 2015 and 2017).

An important dimension of "Las 17" was that the legal actions were promoted along with a large-scale national and international media campaign called "Una flor para las 17" (A flower for the 17). Part of this strategy entailed having public figures from culture, science and international entities take a public stance in favor of the "Las 17". Another high-impact action of this strategy consisted in making the life stories of the 17 women imprisoned available to the general public. This information was disseminated in different formats, such as short films that documented the life history of each of the women in "Las 17" and detailing the human rights violations committed during the legal processes that condemned them, among other details. The dissemination of the life stories of "Las 17" revealed some of the consequences suffered by women vis-à-vis the absolute legalization of abortion in El Salvador. The life stories brought the attention of international media and, as a result, various journalistic and documentary reports were produced by the BBC, Deutsche Welle, Al-Jazeera, El País, and The Guardian, among others (AGRUPACIÓN CIUDADANA, 2020). The social and media campaigns contributed to translate the technical language in the judicial sentences to a broader audience, putting women's bodies, faces and life stories in the spotlight, providing a new light to the legal discussions on abortion. A decisive aspect to stress is how media outlets addressed the topic. As several actors of the feminist movements in El Salvador have expressed on occasion, media strategies are as important as the legal strategies, given the pressure that the press (particularly the international press) places on specific legal and political operators (BENAVIDES, 2019).

Another important element to consider in "Las 17" campaign was also the support of the international human rights organizations from abroad. For instance, Amnesty International's general director addressed El Salvador's Legislative Assembly, arguing in favor of granting the pardons (BERNAL, 2014). The Union Confederation of the Workers' Commission from Valencia (Spain), different United Nations experts (OFFICE OF THE UNITED NATIONS

9 In 2013, the Centro Las Libres reported that in Mexico there were 157 women who had been informed on for abortion, and who were finally charged with homicide (EL UNIVERSAL, 2010). 
HIGH COMMISSIONER FOR HUMAN RIGHTS, 2015), the International Federation of Women in Legal Careers, and the European Parliament, among others, presented briefs to the Supreme Court in favor of the pardons. International pressure also came from the presentation of documents supporting the campaign in different Salvadoran embassies and consulates in Latin America and Europe (PEÑAS DEFAGO, 2018b).

As a consequence of the pardon petitions, Guadalupe was the only one out of the group of seventeen to obtain her freedom. After the pardons resolution, more than ten women who were part of "Las 17" were released within the framework of the next feminist campaign called "Las 17+" (AGRUPACIÓN CIUDADANA, 2020).

The impact of "Las 17," however, went beyond the specific pardon petitions. In 2016, Lorena Peña, member of the lower house of congress, introduced a bill to decriminalize abortion in cases of rape, when the woman's life or health is at risk, and when human trafficking is at stake. It was the first time in twenty years that a bill had been introduced to reform the country's abortion law. ${ }^{10}$ In support of the bill, women's organizations presented a letter containing more than 200 signatures collected in El Salvador and around the world.

After this campaign, local human rights organizations joined Agrupación Ciudadana and others feminist organizations in the defense of legal actions and campaigns to free imprisoned women and to promote the abortion debate locally.

However, the debate sparked by the "Las 17" campaign also inspired law reform efforts against abortion. In 2014, a congresswoman from the Nationalist Republican Alliance requested to the Legislative Assembly a public statement against abortion. This presentation happened after Amnesty International filed a report to the Legislative Assembly requesting the pardon of "Las 17." Moreover, in 2016, congressman Ricardo Velásquez Parker (Nationalist Republican Alliance) introduced a bill to reform the Criminal Code to extend abortion penalties to thirty and fifty years of imprisonment, on the grounds that abortion entails homicide (FCMUJERES, 2016). The bill attempted to legitimate the conviction not only of women who have had abortions but also, as in the case of "Las 17," of women who have been charged with homicide after suffering miscarriages.

On April 30, 2018, the 2015-2018 legislative term ended without any of the bills coming up for debate, and in consequence both bills lost their parliamentary status. If Congress wants to address them, new bills need to be re-introduced by a member of Congress.

10 In 1998, congresswoman Ofelia Navarrete (FMLN) submitted a proposal to reverse the total ban on abortion. The bill sought to decriminalize abortion in cases in which the woman's life was at risk. Given that in 1999 presidential elections would be held, Navarrete was forced to withdraw the proposal due to pressures from her own party, FMLN, which was not interested in allowing abortion to be a part of its electoral campaign (FREEDMAN, 2013). 


\section{3. “LAS i7+": The Struggle Continues}

After the pardon petitions were ruled on by the Supreme Court, the "Las 17" campaign became "Las 17+" and prompted new socio-legal actions, such as requests to commute sentences, requests to revise sentences, petitions for alternatives to imprisonment, and habeas corpus petitions (PEÑAS DEFAGO, 2018a and 2018b). As a consequence, more than ten women were freed between 2017 and 2019 (AGRUPACIÓN CIUDADANA, 2020).

One of the most notorious cases among these was the case of Evelyn, one of the original seventeen women, who had been sentenced to thirty years in prison after suffering a miscarriage at home. At the time of her miscarriage, Evelyn was eighteen years old. Following her conviction, her defense filed an appeal. This measure was taken by Agrupación Ciudadana together with the Human Rights Institute from Universidad Católica Centroamericana and the Fundación de Estudios para la Aplicación del Derecho, two of the most renowned human rights organizations in El Salvador. In December 2018, the Supreme Court overturned Evelyn's sentence, holding that an infringement of a reasoned judgment had been committed, and ordered a re-trial.

After this ruling, Evelyn's defense requested that she be released on parole after serving three years. In February 2019 she was released and waited for a new trial. ${ }^{11}$ In August 2019, the judge of the new trial in a lower court in Cojutepeque found Evelyn innocent of the charges and absolved her, reasoning that the Public Prosecutor's Office was unable to demonstrate her involvement in the event. The new trial thus determined that there was no crime whatsoever in the out-of-hospital emergency delivery. However, Evelyn's legal conundrum was not over yet. Days after her absolution, the Public Prosecutor's Office appealed the Cojutepeque trial's decision and ratified the original petition for a forty-year imprisonment of Evelyn. In an attempt to help put an end to women's cruel and systematic persecution, organizations at the national and international level have been demanding justice by conducting several public actions, all of which are labeled with the hashtag \#JusticiaParaEvelyn. As with the mobilizations of "Las 17," part of the international pressure in this case also came from the presentation of documents supporting the campaign "JusticiaParaEvelyn" in different Salvadoran embassies and consulates in Latin America and Europe. On June 2020, the Appeals Chamber of Cojutepeque confirmed the absolution of Evelyn.

As it was mentioned above, according to official records of the Agrupación Ciudadana, more than ten women were released by legal and political actions framed in the campaign "Las 17+" (AGRUPACIÓN CIUDADANA, 2020).

The reality of women in El Salvador continues to be difficult even after they are released. According to the latest report of the Agrupación Ciudadana (2020), after obtaining their

11 This was not the first time that women's organizations had implemented this measure. In April 2016, Agrupación Ciudadana managed to obtain permission for Flor Arely to be released on parole. Flor Arely had also been accused of homicide after suffering a miscarriage. 
freedom and as a result of the social stigma that weighs on them, many women had difficulties to get a job, as well as to reintegrate into their families and community. Given this, women's organizations recently inaugurated new strategies, such as the "Las Liberadas" initiative, which makes it possible to strengthen ties of solidarity between liberated women, as well as promoting support networks (AGRUPACIÓN CIUDADANA, 2020).

Recently, legal actions have extended into grounds for complaint about the different sorts of sexual violence that caused these women to become pregnant in the first place. In 2019, feminist organizations mobilized around the case of Imelda, who was in prison for abortion. Her pregnancy, however, had been the result of sexual abuses committed by her stepfather since Imelda was eleven years old. Imelda's abuser received a thirteen-year sentence for the sexual abuses, and the Public Prosecutor's Office requested that Imelda receive a twenty-year conviction for the crime of abortion (ROSALES MARTEL, 2018). In other words, Imelda's crime was considered worse than the crime of her abuser. The unfair reality that Imelda's case exposes is also evident across the country. According to the Ministry of Public Health, in 2016, 21,000 girls under the age of eighteen became pregnant as a result of rape (LÓPEZ, 2018). Between 2013 and 2016, the Public Prosecutor's Office brought to trial only 27\% of the cases of complaints of sexual abuse. With respect to the trials in the same period, only $10 \%$ of these received a sentence (NÓCHEZ and AGUIRRE, 2017).

Today, national and international legal mobilization continues in El Salvador, exposing several arenas and actors involved in the disputes over abortion. The complexity of those mobilizations makes it necessary to approach these disputes in terms of a transnational logic (JURIS and KHASNABISH, 2013). Disputes over abortion transcend the national sphere and incorporate different levels of analysis and actions, such as the regional, international and local levels. This is important also because we need to consider the more recent backlash from the conservative actors, who made international and legal alliances after the re-politicization of the abortion debate in El Salvador.

In terms of backlash, one key dimension to consider is how the growing politicization of abortion gave rise to the creation of new self-proclaimed pro-life organizations and international alliances between conservative organizations. Once "Las 17" campaign was launched, the Salvadoran organization Sí a la Vida, together with the Alliance Defending Freedom (a U.S. NGO specialized in conservative litigation), called for new lawyers to join the pro-life cause in El Salvador (JOMA, 2015). Also as part of the backlash, the NGO Sí a la Vida extended its influence to the international arena of human rights. In 2015, Si a la Vida asked to be recognized as an organization by the Organization of American States with the purpose of intervening as a member of the civil society in OAS's General Assembly (PERMANENT COUNCIL OF THE ORGANIZATION OF AMERICAN STATES, 2015). ${ }^{12}$

12 The actions of the conservative actors in the international human rights system in order to resist the legal reforms on abortion, among other sexual and reproductive rights, are not exclusive of El Salvador. As 
Furthermore, the media and social media campaigns around "Las 17" were also emulated by conservative actors. In 2020 a documentary titled "El fraude de las 17" (The fraud of the 17) was launched by El Faro Film, an Argentinian pro-life audiovisual studio. ${ }^{13}$ The launch of the documentary and its extensive dissemination coincided with the news that El Salvador could be internationally condemned by the Inter-American Court of Human Rights for the case of Manuela.

On March 10 and 11, 2021, the Inter-American Court of Human Rights heard arguments in the Manuela vs. El Salvador case. ${ }^{14}$ The future resolutions of the Inter-American Court (in Manuela's and Beatriz' cases) can have an impact not only in El Salvador but also on the abortion legalization debates throughout Latin America. The recent experience of El Salvador also shows how the repolitization of the abortion debate could generate new articulations between conservative actors at national and international spheres (MORÁN FAÚNDES and PEÑAS DEFAGO, 2020).

\section{Lessons from the Salvadoran Case: Open Debate beyond El Salvador}

The case of El Salvador shows how social and cultural strategies can be combined with legal strategies to resist the effects of a total ban on abortion and promote legislative and social change. On occasion, these actions may translate into effects that are not just legal but also symbolic in the long term. Examples of those effects are changes in the perspective the media has on abortion, as well as new alliances with health and human rights sectors, and academia, among others. In "Las 17," the proper names (sometimes fictitious at the request of the women themselves) embodied the life stories and the horror women experienced when facing the judicial, criminal, and very often medical systems. The public dissemination of their stories has played a key role in the impact of the legal actions. These strategies contributed as well to propel social and political debates about the real-life consequences to Salvadoran women of the total abortion ban system.

Lynn Morgan (2014) points out, since the mid-1990s the participation of the Holy See in the UN Conferences in El Cairo (1994) and Beijing (1995) made clear the importance of those spaces for the advancement of conservative strategies. If the participation of the conservative groups in the international human rights system - especially the United Nations - is not new (CHAMBERLAIN, 2006; YAMIN, DATTA and ANDION, 2018), the novelty here is the intensification of this participation in the last decade at OAS (MORGAN, 2021).

13 For more information about El Faro Film, see https://farofilms.org/.

14 To access the videos of the hearings, see Corte Interamericana de Derechos Humanos, Audiencia Pública, caso Manuela y otros vs. El Salvador, parte 1, 2021. Available at: https://www.youtube.com/watch?v= PPOkQEQugkk. 
Some of these extra-legal results of contemporary feminist campaigns can be observed through the bridges between strategies and activists in the region and the world, which have been giving way to a reconstruction of law as a form of "intersubjective knowledge" (MCCANN, 1998). In this sense, the feminist legal strategies deployed in El Salvador not only changed the narrative about abortion law within the domestic borders - from an exclusive criminal law issue to a human rights issue - but also changed the narrative of human rights and abortion, providing new perspectives to analyze obstacles to access abortion as a violation of human rights. The faces and life stories of the activists in El Salvador brought new meaning to human rights law, adding voices to transform its interpretation. Literature on the constitutionalization of abortion law in a comparative approach could gain a valuable perspective taking the case of El Salvador as a new experience of feminist legal mobilization around abortion changing the narrative of constitutional and human rights law. What we have learnt and affirmed with the Salvadoran feminist movement strategies is that to impulse legal reform, law is simply not enough (SIEGEL, 2014; BERGALLO and RAMÓN MICHEL, 2018; BERGALLO, 2018; MACHADO and COOK, 2018). The path that feminist legal mobilization has followed in El Salvador demonstrates how the debate around abortion law reform has changed radically: it is no longer framed only in terms of a religious morality (a morality that for years has guided the country's political morality) but rather as an issue of human rights, understood from human rights legal and cultural dimensions. Even though many challenges remain, and the conservative backlash is re-articulating itself in the face of the new context, the matter is still on the agenda as a result of years of feminist activism. Without question, this is one of the most remarkable successes of the "Las 17" and "Las 17+" campaigns: raising awareness of the consequences that a total ban on abortion has for women's life and health, and giving evidence of how poorly the legal and medical systems work for women. The campaigns have also helped force the debate on abortion in El Salvador onto the public agenda not just as a women's issue but as a matter that must be urgently addressed to strengthen democracy and to respect human rights in general.

Another lesson learned from the case of El Salvador refers to how feminist movements, despite difficulties, tried to build alliances and influence institutional life to achieve legal reform. Despite the extreme difficulties of the Salvadoran context, it is possible to see positive changes resulting from the initial legal strategies that the feminist movements launched in 2006. While in that first legal action movements needed to seek allies abroad, today feminist organizations in El Salvador are stronger and they have academic, legal, and medical allies, among other fields, not only abroad but also in their own country.

One of the key collaborative processes in El Salvador refers to the different actions that are articulated by the "transnational advocacy networks" (KECK and SIKKINK, 1998). The coordinated work between international and national networks of feminist movements and human rights activists managed to progressively generate and circulate information on the situations of incarcerated women, achieving real and symbolic support from international and 
national actors. This was key to efforts in holding state actors accountable to the consequences produced by a criminal system such as the Salvadoran one. The case of El Salvador is also useful to think about the boomerang effect of this transnational mobilization (KECK and SIKKINK, 1998). As we have tried to show in this work, and especially since the Beatriz case, the transnational mobilization around abortion became a key element in the face of an adverse institutional and social scenario for the political and legal mobilization to demand an abortion legal reform. Socio-legal mobilization developed by feminist movements in El Salvador is a good model to see how it is possible to pave possible paths for dialogue and action from transnational alliances when the communication channels between the State and national public actors are complex and/or impossible.

The regional precedents that inspired the creation of Agrupación Ciudadana, as well as the pardon strategies, show the operation of information flows and shared strategies between feminist organizations that work in contexts of great hostility. The case of El Salvador is a unique experience that evidences how solidarity among different social movements is possible, even in contexts of extreme criminalization. These networks go beyond feminist movements and national borders. The alliances and networks created in El Salvador around the issue of abortion shed light on the importance of collaborative processes. These processes entail a continuous flow of information and joint actions that go beyond national borders but still have a great impact on local scenarios and debates.

Therefore, we believe that the case of El Salvador offers essential insights to help design feminist strategies for other contexts, not only in Latin America but also in the United States and Europe, where we can see new attempts to introduce total abortion bans have recently emerged.

\section{ACKNOWLEDGEMENTS}

The authors would like thank Agrupación Ciudadana por la Despenalización del Aborto en El Salvador for their generosity with them, and for their work towards the full realization of women's human rights in El Salvador. This paper however reflects only the authors' opinions.

\section{REFERENCES}

ABORTO en El Salvador: las mujeres acusadas de homicidio y encarceladas tras perder embarazos. BBC News Mundo, July 15, 2019. Available at: https://www.bbc.com/mundo/noticias-48997325. 
ACTIVISTA espera que otras salvadoreñas presas por aborto sean libres en 2020. La Vanguardia, December 31, 2019. Available at: https: / /www.lavanguardia.com/vida/20191231/472664163006/ activista-espera-que-otras-salvadorenas-presas-por-aborto-sean-libres-en-2020.html.

AGARESO. Indebted to AllWomen: A Story about Abortion Criminalization in El Salvador.YouTube, December 19, 2019. Available at: https://www.youtube.com/watch?v=UcanNtb_woM.

AGRUPACIÓN CIUDADANA POR LA DESPENALIZACIÓN DEL ABORTO TERAPÉUTICO, ÉTICO Y EUGENÉSICO. Del hospital a la cárcel: consecuencias para las mujeres por la penalización sin excepciones, de la interrupción del embarazo en El Salvador. Reporte de investigación, San Salvador, 2020.

AGRUPACIÓN CIUDADANA POR LA DESPENALIZACIÓN DEL ABORTO TERAPÉUTICO, ÉTICO Y EUGENÉSICO. Del hospital a la cárcel: consecuencias para las mujeres por la penalización sin excepciones, de la interrupción del embarazo en El Salvador. San Salvador: Agrupación Ciudadana por la Despenalización del Aborto Terapéutico, Ético y Eugenésico, 2012.

ARANGO OLAYA, Mónica. Inter American Court of Human Rights provisional measures adopted in B. v. El Salvador case and the strengthening of reproduction rights in the inter-American system. Anuario de Derechos Humanos, v. 10, p. 177-185, 2014.

BENAVIDES, Sofía. Radiografía del aborto en El Salvador: por qué es una pelea estratégica para toda América Latina. Infobae, September 8, 2019. Available at: https://www.infobae.com/america/ america-latina/2019/09/08/radiografia-del-aborto-en-el-salvador-por-que-es-una-pelea-estrategicapara-toda-america-latina.

BERER, Marge; HOGGART, Lesley. Progress toward Decriminalization of Abortion and Universal Access to Safe Abortions: National Trends and Strategies. Health and Human Rights Journal, v. 21, n. 2 , p. 79-83, 2019.

BERGALlO, Paola. Cosmovisiones constitucionales e interrupción del embarazo. Pensar en Derecho, n. 12, p. 43-79, 2018.

BERGALLO, Paola; RAMÓN MICHEL, Agustina. La constitucionalización del aborto y sus encuadres en las altas cortes de América Latina. In: BERGALLO, Paola; RAMÓN MICHEL, Agustina (ed.). La reproducción en cuestión: investigaciones y argumentos jurídicos sobre aborto. Buenos Aires: Eudeba, 2018.

BERNAL, Laura. Amnistía Internacional pide a CSJ indulto para "las 17”. Contrapunto, September 24, 2014. Available at: https: / /www.contrapunto.com.sv/archivo2016/sociedad/genero/amnistia-internacionalpide-a-csj-indulto-para-las-17. 
BUKELE: Estoy a favor del aborto cuando esté en peligro la madre; creo que el matrimonio es entre hombre y mujer. El Salvador Times, November 5, 2018. Available at: https://www.elsalvadortimes. $\mathrm{com} / \mathrm{articulo/politicos/bukele-favor-causal-aborto-matrimonio-personas-mismo-sexo/2018103119}$ 3602050584.html.

CABAL, Luisa; ROA, Mónica; SEPÚLVEDA-OLIVA, Lilian. What Role Can International Litigation Play in the Promotion and Advancement of Reproductive Rights in Latin America? Health and Human Rights Journal, v. 7, n. 1, p. 50-88, 2003.

CABAL, Luisa; TODD-GHER, Jaime M. Reframing the Right to Health: Legal Advocacy to Advance Women's Reproductive Rights. In: CLAPHAM, Andrew; ROBINSON, Mary (ed.). Realizing the Right to Health. Zurich: Rüffer and Rub, 2009.

CENTER FOR REPRODUCTIVE LAW AND POLICY. Persecuted: Political Process and Abortion Legislation in El Salvador. A Human Rights Analysis. New York: Center for Reproductive Law and Policy, 2001.

CHAMBERLAIN, Pam. UNdoing Reproductive Freedom: Christian Right NGOs Target the United Nations. Cambridge, MA: Political Research Associates, 2006.

CORREAA, Sonia; PARKER, Richard. Sexualidade e política na américa latina: histórias, interseções e paradoxos. Rio de Janeiro: ABIA, 2011.

EL SALVADOR es uno de los pocos países que aún no han decidido que la vida de las mujeres importa. Entrevista a Sara Garcia. CIVICUS, June 27, 2017. Available at: https://www.civicus.org/index. $\mathrm{php} / \mathrm{es} / \mathrm{medios}-\mathrm{y}$-recursos/noticias/entrevistas/2879-el-salvador-es-uno-de-los-pocos-paises-queaun-no-han-decidido-que-la-vida-de-las-mujeres-importa.

FANNI, Simona. The Protection of the Right to Life at the Intersection between Reproductive Rights and Scientific Progress in the Jurisprudence of the Inter-American Court of Human Rights and the European Court of Human Rights. Araucaria. Revista Iberoamericana de Filosofía, Política y Humanidades, v. 20, n. 40, 2018.

FCMUJERES. Arena Diputado Velásquez Parker presenta iniciativa para proteger derecho inherente a la vida desde la concepción. July 2016. Available at: https: / /www.fcmujeres.org/el-salvador-criminalizacione-intento-de-endurecer-penas-por-aborto/.

FEUSIER, Oswaldo. Desde el dogmatismo hacia la exclusión: apuntes sobre el delito de aborto en El Salvador. Revista Redbioética /UNESCO, v. 2, n. 12, p. 46-69, 2015. 
FEUSIER, Oswaldo. Pasado y presente del delito de aborto en El Salvador. Universidad Centroamericana José Simeón Cañas, 2012. Available at: http://www.uca.edu.sv/deptos/ccjj/media/archivo/95bbb4_ pasadoypresentedeldelitodeabortoenelsalvador.pdf.

FREEDMAN, Elaine. El caso de Beatriz: ¿Quién tiene la palabra? Revista Envío, n. 376, 2013.

GARCÍA, C.; OCAMPO, S. Centro Las Libres: 157 permanecen recluidas. La Jornada, January 23, 2014. Available at: http://www.jornada.unam.mx/2014/01/23/estados/027n2est.

GOMÉZ, Ricardo. PRI pide liberar mujeres presas por aborto. El Universal, August 23, 2010. http:/ / archivo. eluniversal.com.mx/notas/703639.html.

GOVERnMent Of EL SALVADOR. Código Penal. Decreto n. 1030, 1974.

GOVERnMENT OF EL SALVADOR. Código Penal. Decreto n. 270, 1973.

HERRERA ARGUETA, Morena; UGARTE, Ana. Informe El Salvador: Colectiva Feminista para el Desarrollo Local. Balance de cuatro experiencias mesoamericanas en torno a la despenalización/penalización del aborto. San Salvador: La Colectiva, 2009.

HTUN, Mala. Sex and the State: Abortion, Divorce, and the Family Under Latin American Dictatorships and Democracies. Cambridge: Cambridge University Press, 2003.

IACHR. Report n. 120/17. Petition 2003-13. Admissibility. Beatriz. El Salvador. September 7, 2017.

IACHR. Consultation on Module II: Precautionary Measures. October 5, 2012.

INTER-AMERICAN COURT OF HUMAN RIGHTS. Caso Manuela y otros vs. El Salvador, December $11,2020$.

INTER-AMERICAN COURT OF HUMAN RIGHTS. Asunto B.: medidas provisionales respecto de El Salvador, May 29, 2013.

IRAHETA, Paula. Diagnóstico sobre las mujeres salvadoreñas 2009. San Salvador: Concertación Feminista Prudencia Ayala, 2009.

JARAMILLO SIERRA, Isabel; SIERRA, Tatiana Alfonso. Mujeres, cortes y medios: la reforma judicial del aborto. Bogotá: Siglo del Hombre, 2008. 
JOMA, Susana. Neydy Casillas: existe una confusión generalizada sobre el aborto como "derecho". Elsalvador.com, February 15, 2008. Available at: https: / / historico.elsalvador.com/historico/145545/neydycasillas-existe-una-confusion-generalizada-sobre-el-aborto-como-derecho.html.

JURIS, Jeffrey S.; KHASNABISH, Alexander (ed.). Insurgent Encounters: Transnational Activism, Ethnography, and the Political. Durham: Duke University Press, 2013.

KANE, Gillian. Abortion Law Reform in Latin America: Lessons for Advocacy. Gender and Development, v. 16, n. 2, p. 361-75, 2008.

KECK, Margaret; SIKKINK, Kathryn. Activists beyond Borders. Ithaca: Cornell University Press, 1998.

LÓPEZ, Jaime. Policía registra 1,376 niñas violadas en 2017 en El Salvador. ElSalvador.com, February 25, 2018. Available at: https://www.elsalvador.com/noticias/nacional/policia-registra-1376-ninasvioladas-en-2017-en-el-salvador/453882/2018.

MACHADO, Marta; COOK, Rebecca. Constitutionalizing Abortion in Brazil. Revista de Investigações Constitucionais, v. 5, n. 3, p. 185-231, 2018.

MCCANN, Michael. Law and Social Movements: Contemporary Perspectives. Annual Review of Law and Social Science, n. 2, p. 17-38, 2006.

MCCANN, Michael. How Does Law Matter for Social Movements? In: GARTH, Bryant; SARAT, Austin. How Does Law Matter? Evanston: Northwestern University Press, 1998.

MCCANN, Michael. Rights at Work: Pay Equity Reform and the Politics of Legal Mobilization. Chicago: University of Chicago Press, 1994.

MORÁN FAÚNDES, José Manuel; PEÑAS DEFAGO, María Angélica. Una mirada regional de las articulaciones neoconservadoras. Rupturas y continuidades transnacionales. In: TORRES SANTANA, Ailynn (ed.). Derechos en Riesgo en América Latina. Bogotá: Ediciones desde Abajo/Fundación Rosa Luxemburgo, 2020.

MORGAN, Lynn. Global Anti-Abortion Coalition Targets the Organization of American States. NACLA, June 4, 2021. Available at: https: / / nacla.org/news/2021/06/04/global-anti-abortion-coalition-targetsorganization-american-states.

MORGAN, Lynn. Claiming Rosa Parks: Conservative Catholic Bids for "Rights" in Contemporary Latin America. Culture, Health \& Sexuality, v. 16, n. 10, p. 1245-1259, 2014. 
NEJAIME, Doug. The Legal Mobilization Dilemma. Emory Law Journal, v. 61, n. 4, p. 664-733, 2012.

NEW YORK TIMES. Pro-Life Nation. Jack Hitt, April 9, 2006. Available at: https://www.nytimes. com/2006/04/09/magazine/prolife-nation.html.

NÓCHEZ, María Luz; AGUIRRE, Laura. Un paraíso para los violadores de menores. El Faro, January 31, 2017. Available at: https: / / especiales.elfaro.net/es/el_paraiso_de_violadores/impunidad/ 19894/Porqu\%C3\%A9-queda-impune-el-90_de-las-violaciones-a-menores.htm.

OFFICE OF THE UNITED NATIONS HIGH COMMISSIONER FOR HUMAN RIGHTS. Indulto a Guadalupe: expertos de la ONU instan a El Salvador a que se indulte a las mujeres que se encuentran en prisión por haber tenido complicaciones durante el embarazo y a derogar las leyes de aborto restrictivas. January 28, 2015.

ORGANIZATION OF AMERICAN STATES. CIDH presenta caso sobre El Salvador a la Corte IDH. October 10, 2019. Available at: https: / /www.oas.org/es/cidh/prensa/comunicados/2019/255.asp.

PECHENY, Mario; DE LA DEHESA, Rafael. Sexualidades y políticas en América Latina: un esbozo para la discusión. Paper presented at Diálogo Latinoamericano sobre Sexualidad y Geopolítica, Rio de Janeiro, Brazil, August 24, 2009.

PEÑAS DEFAGO, María Angélica. El aborto en El Salvador: tres décadas de disputas sobre la autonomía reproductiva de las mujeres. Península, v. 13, n. 2, p. 213-34, 2018 a.

PEÑAS DEFAGO, María Angélica. "Las 17”: estrategias legales y políticas para legalizar el aborto en El Salvador. Revista de Bioética y Derecho, n. 43, p. 91-107, 2018 b.

PEÑAS DEFAGO, María Angélica; CÁNAVES, Violeta. Movilización legal de mujeres y aborto: el caso de El Salvador. In: BERGALLO, Paola; JARAMILLO SIERRA, Isabel; VAGGIONE, Juan (ed.). El aborto en América Latina: estrategias jurídicas para luchar por su legalización y enfrentar las resistencias conservadoras. Buenos Aires: Siglo XXI, 2018.

PERMANENT COUNCIL OFTHE ORGANIZATION OF AMERICAN STATES. Solicitud de registro presentada por la Fundación “Sí a la Vida”. October 19, 2015.

REBOUCHÉ, Rachel. Abortion Rights as Human Rights. Social and Legal Studies, v. 25, n. 6, p. 765 $82,2016$. 
ROMERO DE URBIZTONDO, Alberto; CÁCERES DE LEÓN, Keila Eunice. Los que se oponen a los derechos de las mujeres, población LGTBI, derechos sexuales y reproductivos. San Salvador: Agrupación Ciudadana por la Despenalización del Aborto, 2019.

ROSALES MARTEL, Metzi. Imelda Cortez: un caso de versiones y aversiones. Factum, November 11, 2018. Available at: https://www.revistafactum.com/imelda-cortez-un-caso-de-versiones-y-aversiones.

RUIBAL, Alba. Movilización y contra-movilización legal: propuesta para su análisis en América Latina. Política y Gobierno, v. 22, n. 1, p. 175-98, 2015.

RUIBAL, Alba; FERNÁNDEZ ANDERSON, Cora. Legal Obstacles and Social Change: Strategies of the Abortion Rights Movement in Argentina. Politics, Groups, and Identities, v. 8, n. 4, p. 698-713, 2020.

SALA CONSTITUCIONAL DE LA CORTE SUPREMA DE JUSTICIA. Sentencia 310, May 28, 2013.

SALA CONSTITUCIONAL DE LA CORTE SUPREMA DE JUSTICIA. Sentencia 67, April 13, 2011.

SALA CONSTITUCIONAL DE LA CORTE SUPREMA DE JUSTICIA. Sentencia 18, November 20, 2007.

SIEGEL, Reva. The Constitutionalization of Abortion. In: COOK, Rebecca J.; ERDMAN, Joanna N.; DICKENS, Bernard M. (ed.). Abortion Law in Transnational Perspective: Cases and Controversies. Philadelphia: University of Pennsylvania Press, 2014.

VAGGIONE, Juan Marco. Reactive Politicization and Religious Dissidence: The Political Mutations of the Religious. Social Theory and Practice, v. 31, n. 2, p. 165-88, 2005.

VANHALA, Lisa. Legal Mobilization. Oxford Bibliographies, 2018. Available at: https://www. oxfordbibliographies.com/view/document/obo-9780199756223/obo-9780199756223-0031.xml.

VITERNA, Jocelyn. The Left and "Life" in El Salvador. Politics and Gender, v. 8, n. 2, p. 248-254, 2012.

VITERNA, Jocelyn; GUARDADO BAUTISTA, José Santos. Independent Analysis of Systematic Gender Discrimination in the El Salvador Judicial Process against 17Women Accused of the Aggravated Homicide ofTheir Newborns. 2014. Available at: https: / / scholar.harvard.edu/files/viterna/files/viterna_guardado_ white_paper_english.pdf.

YAMIN, Alicia Ely. Beyond Compassion: The Central Role of Accountability in Applying a Human Rights Framework to Health. Health and Human Rights Journal, v. 10, n. 2, p. 1-20, 2008. 
YAMIN, Alicia Ely; BERGALLO, Paola. Narratives of Essentialism and Exceptionalism: The Challenges and Possibilities of Using Human Rights to Improve Access to Safe Abortion. Health and Human Rights Journal, v. 19, n. 1, p. 1-11, 2017.

YAMIN, Alicia Ely; DATTA, Neil; ANDIÓN, Ximena. Behind the Drama: The Roles of Transnational Actors in Legal Mobilization over Sexual and Reproductive Rights. Georgetown Journal of Gender and the Law, v. 19, n. 3, p. 533-570, 2018.

\section{HOW TO QUOTE THIS ARTICLE:}

PEÑAS DEFAGO, María Angélica; CÁNAVES, Violeta. Socio-Legal Strategies against a Total Abortion Ban in El Salvador: Alliances in Hostile Contexts. Revista Direito GV, São Paulo, v. 17, n. 3, set./dez. 2021, e2147. https://doi.org/10.1590/23176172202147

\section{María Angélica Peñas Defago}

Adjunct Researcher at the National Council of Scientific and Technical Research, Argentina. Professor of Sociology of Law, National University of Córdoba. Fellow at the Centre of Law and Social Transformation, Chr. Michelsen Institute, University of Bergen. Member of Red ALAS.

angelicapdefagolunc.edu.ar

\section{Violeta Cánaves}

Professor of Constitutional LaW, National University of Litoral, Argentina. LlM and JSD Candidate, Yale LaW School. Member of Red Alas.

violeta.canavesagmail.com 